\title{
Determination of adsorption efficiency based on cation exchange capacity related to red earth, bone meal and pulverised fly ash as ameliorants to lead contaminated soils
}

\author{
${ }^{1}$ E. Gatima, ${ }^{2}$ M. Mwinyihija and ${ }^{1}$ K. Killham \\ ${ }^{1}$ School of Biological Sciences, Plant and Soil Sciences, University of Aberdeen, St. Machar Drive, Cruickshank \\ Building, Aberdeen, U.K. \\ ${ }^{2}$ Veterinary laboratories Kabete, Private Bag 00625, Kangemi, Nairobi, Kenya
}

Received 30 March 2006; revised 7 March 2006; accepted 15 March 2006; available online 25 June 2006

\begin{abstract}
Efficient treatment strategies to reduce the toxicity of metal contaminated soil using cost effective techniques such as naturally available ameliorants and industrial waste have emerged. Three easily available amendments were determined: Bone meal, red earth/mud and pulverised fly ash (PFA). The application of ameliorants offered a possible alternative in situ remediation of contaminated sites without disruption to the ecosystem profile. In comparison to other ameliorants Red earth/mud was found to be efficient in intercepting lead leaching from soil amended with different lead compounds based on CEC (Cmol/g). This was associated with the heterogeneous adsorbency principle in red mud which is associated with its ability to bind metal ions $\left(\mathrm{M}^{2+}\right)$ onto one or two types of surface sites at $\mathrm{pH}<$ 6.0. However areas that need to be studied and assessed (for public health concerns) critically for wide spread application of all the ameliorants include off-site effects of the ameliorants.
\end{abstract}

Key words: Lead contamination, adsorption efficiency, red earth, bone meal, pulverised fly ash

\section{INTRODUCTION}

The stabilisation of metals as phosphates in metal contaminated soil is increasingly recognised as a potentially cost effective in situ remediation technology (Cotter-Howells, 1996). The current method of treating metal-contaminated soils essentially focuses on isolating the soil from the ecosystem by capping or removal of the soil and dumping it elsewhere (Wood, 1997). Thus cheaper and less damaging ways of removing toxic metal from soils are clearly needed rather than the mechanical techniques generally in use. As a result, bioremediation, using living organism to reduce the environmental hazards associated with industrial and other waste, has been increasingly examined as a potentially practical and more cost effective technology than the soil replacement, solidification, or washing strategies commonly used (Cunningham et al., 1995). For example previous studies have shown that the costs associated with phytoremediation are lower than conventional methods (Macek et al., 2000). Phytoextraction technologies have been widely used,

\footnotetext{
*Corresponding author, Email: mmwinyi@gmail.com

Tel.: +254-0722 429807; Fax: +254-020 631790
}

but further development is still required before implementation on large-scale remediation (Salt et al., 1998). However limitations associated with the use of plants for remediation of organic and heavy metal pollutants in soil include the climatic and geological conditions of the site to be cleaned, the temperature, altitude, and soil type at the site. To further explore the associated advantage of applying ameliorants, three easily available amendments were used during this study: Bone meal, red earth/mud and pulverised fly ash (PFA). Their ecotoxicological importance as ameliorants have been discussed widely but their efficiencies on remediating lead contaminated soils are yet to be documented. For example, generally red earth is a by-product of the manufacture of alumina that contains iron oxide (30-50\%) with significant amounts of silica, alumina, calcium oxide and titanium, dispersed in highly alkaline and caustic liquor (Nguyen and Boger, 1998 and Alvarez et al., 1999). The treatment and disposal of bauxite residue is a major operation and accounts for $30-50 \%$ of operations in an alumina refinery (Nguyen and Boger, 1998). The main 
constituents of red earth are $\mathrm{Al}_{2} \mathrm{O}_{3}(20.24 \%), \mathrm{Fe}_{2} \mathrm{O}_{3}$ (37.84\%), $\mathrm{SiO}_{2}(15.27 \%), \mathrm{Na}_{2} \mathrm{O}(9.43 \%), \mathrm{TiO}_{2}(6.15 \%)$, $\mathrm{CaO}(1.80 \%), \mathrm{Ca} \mathrm{O}_{2}(1.92 \%)$ and other $(0.48 \%)$ (Alp and Goral, 2003). Red earth as a metal toxicity ameliorant has been reported by Friesl et al., (2003) who observed its effect when a consistent decrease of leached $\mathrm{Zn}$ and Ni was noted during their study. Gupta et al., (2001) further reported on the use of red earth from the aluminium industry as an efficient adsorbent for the removal of lead $\left(\mathrm{Pb}^{2+}\right)$ and chromium $\left(\mathrm{Cr}^{6+}\right)$ (following first-order kinetics) over a wide range of concentrations. The removal of the metal ions is through particle diffusion and thermodynamic parameters (Gupta et al., 2001). Bone meal was found to reduce metal release from contaminated soil, increased soil and leachate $\mathrm{pH}$ and decreased soil leachate toxicity (Hodson et al., 2001). Hodson and Valsami-Jones, (1999) looked at the remediation of toxic metal pollution in soils using bone meal and observed that despite the presence of metals in the bonemeal used in the experiments, the addition of bonemeal to metal contaminated soils resulted in a reduction in the concentration of metal ions in solution

leaching from soil. Comparatively the physical and chemical properties of a particular fly ash are dependent on the combustion of the parent coal, conditions during coal combustion, efficiency of emission control devices and practices used during storage and handling (Adriano et al., 1980). Pulverized Fuel Ash (PFA), as it is known in the UK, has been used for over 50 years for a wide range of applications (ACI Committee 226, 1987). Around $60 \%$ to $90 \%$ of PFA comprises as an amorphous glassy material composed of silica, alumina and iron oxides, with other metals present in smaller quantities (Sear et al. 2003). The main constituents, apart from the glass, that are of most significance to the properties of PFA, are calcium oxide (lime) and sulfate (Sear et al. 2003). PFA has very low permeability, which means that there is very little passage of water through it and very little potential leachate. Most trace metals are held in the alumino silicate matrix and are not available to leach. In addition, Chaudhuri et al., 2003, studied the mobility and bioavailability of selected heavy metals in coal ash and sewage sludgeamended acid soil and concluded that soil quality was enhanced with addition of either sludge or ash or their mixtures, with no possible threat to increased bioavailability and mobility of metals. Therefore, the application of ameliorants that were considered to be efficient, cost effective and easily available in this study, offered a possible alternative as a potentially viable source for in situ remediation of contaminated sites without disruption to the ecosystem profile. The aim of this study was to assess the effect of easily available soil amendments on the lability and bioavailability of lead (Pb). In addition lux-based biosensor (Escherichia coli HB101 pUCD607) was carried out to assess $\mathrm{Pb}$ toxicity (i.e. bioavailability) in soil samples due to its wide $\mathrm{pH}$ operating range and as an environmental based organism.

\section{MATERIALS AND METHODS}

The top soil used in these experiments was collected from the top $25 \mathrm{~cm}$ of an agricultural field on the Craibstone estate, which is approximately $9 \mathrm{~km}$ North West of Aberdeen at an elevation of $100 \mathrm{~m}$. Soil was air dried, homogenised and the $\mathrm{pH}$ of the samples measured using a portable, standard, $\mathrm{pH}$ electrode (Hanna HI 8424, Norlab Instrument Ltd., Aberdeen, U.K). The soil $\mathrm{pH}$ was measured using the method described by Allen (1989). A strategy involving application with/without an ameliorant (Red Earth, Bone meal or Pulverised fly ash) on lead spiked soils $\left(\mathrm{PbS}, \mathrm{PbCO}_{3} \mathrm{PbSO}_{4}\right.$ and $\mathrm{PbNO}_{3}$ ) was used to measure the efficacy as described. Thirty pots were packed with either a mixture of soil, lead compounds and ameliorants, or soil with lead compound only. This translated to thirty pots together with 6 pots of control (Table 1).

The same experimental set-up was maintained for the three ameliorants (Bone meal, Red Earth and Pulverised Fly Ash) studied. Bench scale leaching column experiments were carried out in the greenhouse to investigate the suitability of the three ameliorants as remediation treatments for lead contaminated soils.

\section{Artificial rain}

The solution used for the experimental leaching pots had similar composition (Table 2) to that of rain falling in the Aberdeen area based on 4 year average precipitation rates measured between 1989 and 1993 (Fowler, 1987). The ionic composition of the applied artificial rain was as detailed in Table 3. Soil was amended with different lead compounds to obtain a total lead concentration of $1 \mathrm{~g} / \mathrm{kg}$ dry weight soil. The amount required for each lead compound to make up $1 \mathrm{~g}$ of lead added per $\mathrm{kg}$ of soil, is shown as a summary in Table 4 . 
Determination of adsorption...

Table 1: Experimental design depicting number of pots, amount applied (g/L), type of ameliorant (red earth, bone meal and pulverized fly ash) and irrigation rates (mL/3 days)

\begin{tabular}{|c|c|c|c|c|c|c|}
\hline \multirow[t]{2}{*}{$\mathrm{Pb}$ compounds } & \multirow[t]{2}{*}{ Pot No. } & \multirow[t]{2}{*}{$\mathrm{Pb}$ compounds (g) } & \multicolumn{3}{|c|}{ Application rate (g) } & \multirow[t]{2}{*}{ Irrigation rate (mL/3days) } \\
\hline & & & $\operatorname{Re}$ & $\mathrm{Bm}$ & PFA & \\
\hline \multirow[t]{6}{*}{ Pbs } & \#1 & 1.555 & None & None & None & 96 \\
\hline & $\# 2$ & 1.554 & None & None & None & 96 \\
\hline & \#3 & 1.557 & None & None & None & 96 \\
\hline & \#4 & 1.558 & 6.92 & 20.0 & 14.08 & 96 \\
\hline & \#5 & 1.558 & 6.92 & 20.0 & 14.08 & 96 \\
\hline & \#6 & 1.559 & 6.92 & 20.0 & 14.08 & 96 \\
\hline \multirow[t]{6}{*}{$\mathrm{PbCO}_{3}$} & \#1 & 1.309 & None & None & None & 96 \\
\hline & \#2 & 1.308 & None & None & None & 96 \\
\hline & \#3 & 1.310 & None & None & None & 96 \\
\hline & \#4 & 1.309 & 6.92 & 20.0 & 14.08 & 96 \\
\hline & \#5 & 1.309 & 6.92 & 20.0 & 14.08 & 96 \\
\hline & \#6 & 1.309 & 6.92 & 20.0 & 14.08 & 96 \\
\hline \multirow[t]{6}{*}{$\mathrm{PbSO}_{4}$} & $\# 1$ & 1.466 & None & None & None & 96 \\
\hline & \#2 & 1.469 & None & None & None & 96 \\
\hline & \#3 & 1.470 & None & None & None & 96 \\
\hline & \#4 & 1.467 & 6.92 & 20.0 & 14.08 & 96 \\
\hline & \#5 & 1.470 & 6.92 & 20.0 & 14.08 & 96 \\
\hline & \#6 & 1.468 & 6.92 & 20.0 & 14.08 & 96 \\
\hline \multirow[t]{6}{*}{$\mathrm{PbNO}_{3}$} & $\# 1$ & 1.303 & None & None & None & 96 \\
\hline & \#2 & 1.308 & None & None & None & 96 \\
\hline & \#3 & 1.309 & None & None & None & 96 \\
\hline & \#4 & 1.309 & 6.92 & 20.0 & 14.08 & 96 \\
\hline & \#5 & 1.310 & 6.92 & 20.0 & 14.08 & 96 \\
\hline & $\# 6$ & 1.310 & 6.92 & 20.0 & 14.08 & 96 \\
\hline \multirow[t]{6}{*}{ Control } & \#1 & None & None & None & None & 96 \\
\hline & \#2 & None & None & None & None & 96 \\
\hline & \#3 & None & None & None & None & 96 \\
\hline & $\# 4$ & None & 6.92 & 20.0 & 14.08 & 96 \\
\hline & \#5 & None & 6.92 & 20.0 & 14.08 & 96 \\
\hline & \#6 & None & 6.92 & 20.0 & 14.08 & 96 \\
\hline
\end{tabular}

Bm: Bone meal

Re: Red earth

PFA: Pulverised fly ash

Table 2: Preparation of artificial rain as a working standard used for the experimental leaching pots

\begin{tabular}{llllc}
\hline Ions & Molarity of stock & g/L of stock & Source & Molecular weight \\
\hline $\mathrm{Na}^{+}$ & 117.85 & 6.887 & $\mathrm{NaCl}$ & 58.44 \\
$\mathrm{Ca}^{2+}$ & 7.10 & 1.04 & $\mathrm{CaCl}_{2} 2 \mathrm{H}_{2} \mathrm{O}$ & 147.02 \\
$\mathrm{NO}_{3}{ }^{-}$ & 43.82 & 3.507 & $\mathrm{NH}_{4} \mathrm{NO}_{3}$ & 80.04 \\
$\mathrm{NH}_{4}{ }^{+}$ & 11.22 & 1.483 & $\left(\mathrm{NH}_{4}\right)_{2} \mathrm{SO}_{4}$ & 132.14 \\
$\mathrm{H}^{+}$ & 23.89 & - & $\mathrm{H}_{2} \mathrm{SO}_{4}$ & 98 \\
$\mathrm{SO}_{4}{ }^{+2}$ & 6.79 & 1.675 & $\mathrm{MgSO}_{4} \cdot 7 \mathrm{H}_{2} \mathrm{O}$ & 246.48 \\
$\mathrm{Mg}^{2+}$ & 7.56 & 1.536 & $\mathrm{MgCL}_{2} \cdot 6 \mathrm{H}_{2} \mathrm{O}$ & 203.3 \\
\hline
\end{tabular}


Table 3: Ionic concentration ( $\mu \mathrm{mol} / \mathrm{L}$ ) of selected ions and CEC values $(\mu \mathrm{mol} / \mathrm{L})$

\begin{tabular}{lcc}
\hline Ion & $\mu \mathrm{mol} / \mathrm{L}$ & $\mu$ equiv/L \\
\hline $\mathrm{Na}^{+}$ & 117.85 & 117.85 \\
$\mathrm{Ca}^{2+}$ & 7.10 & 14.20 \\
$\mathrm{Mg}^{2+}$ & 14.35 & 28.70 \\
$\mathrm{NH}_{4}^{+}$ & 66.26 & 66.26 \\
$\mathrm{H}^{+}$ & 47.79 & 47.79 \\
$\mathrm{SO}^{2-}$ & 41.91 & 83.82 \\
$\mathrm{Cl}^{-}$ & 147.16 & 147.16 \\
$\mathrm{NO}_{3}^{-}$ & 43.82 & 43.82 \\
\hline
\end{tabular}

Ameliorant (amendments) application

The bone meal (with CEC value of $53.5 \mathrm{cmol} / \mathrm{kg}$ ) was added to the soil in the proportion of $1 \mathrm{~g}$ of bone meal to $50 \mathrm{~g}$ of soil. The amount of red earth (CEC value of $155 \mathrm{cmol} / \mathrm{kg}$ ) added to $1 \mathrm{~kg}$ soil in a pot, was calculated based on quantity of bone meal used in the first experiment. However PFA was 76/53.5 = 1.42 times greater than the CEC value of bone meal.

Calculation of Adsorption efficiency of the ameliorant (based on Cation Exchange Capacity).

The Adsorption efficiency of the ameliorant was expressed in percentage as follows:

$[(\mathrm{Y}-\mathrm{X}) /(\mathrm{CEC} \mathrm{cmol} / 100 \mathrm{~g})] \mathrm{x} 100$

Where

i) $[$ Non Spiked control $]-[$ Spiked Control $]=\mathrm{X} \mathrm{cmol} / 100 \mathrm{~g}$, ii) $[$ Spiked +Ameliorant $]-[$ Control + Ameliorant $]=Y$ $\mathrm{cmol} / 100 \mathrm{~g}$

Standard quality control measures for both chemical and biological analysis were adopted. Leaching pots were irrigated with artificial rain at a rate equivalent to $655 \mathrm{~mm}$ per year, which was approximately equal to the average annual precipitation rate in Aberdeen. The standard irrigation rate was through one application of $96 \mathrm{ml}$ every 3 days using a watering can (with a multiple drip to provide even distribution). Eventually lead concentration from the collected leachate was determined using Graphite Furnace Atomic Absorption Spectrometry (Pelkin Elmer 3300). Lead toxicity testing was analysed using a biosensor analytical technique described by Mwinyihija et al., 2005, 2006. Generally standard laboratory techniques were used to determine all the other measured parameters including soil texture and particle size analysis as described by Avery and Bascomb, 1974.
Table 4: Amount of lead salts required to make up $1 \mathrm{~g} / \mathrm{kg}$ of lead in potted soil sample

\begin{tabular}{cc}
\hline Lead compounds & $\begin{array}{l}\text { Required amount in } \\
\text { potted sample }(\mathrm{g} / \mathrm{kg})\end{array}$ \\
\hline $\mathrm{PbS}$ & 1.555 \\
$\mathrm{PbSO}_{4}$ & 1.466 \\
$\mathrm{PbCO}_{3}$ & 1.309 \\
$\mathrm{PbNO}_{3}$ & 1.303 \\
\hline
\end{tabular}

Statistical analysis

Two-way analyses of (ANOVA-Analysis of Variance) (except for biosensor experimental data which is Oneway ANOVA) were carried out using the statistical package Minitab for windows, release 12.1 (State College, PA, USA). Mean differences were determined using t-test (paired two samples for means) and Pearson Correlations using Excel program (Microsoft ${ }^{\mathrm{TM}}$ Office 2000). Significant differences between treatments were elucidated using least significance difference (LSD) values. Graphs were generated using SigmaPlot for Windows version 9.0 (Jandel Corporation, CA, and USA).

\section{RESULTS}

The chemical and physical characteristics of Craibstone soil used in this experiment was setup between 2004/05 at the greenhouse of the University of Aberdeen, Plant and Soil department, Aberdeen the results of various parameters are indicated as shown in Table 5. The parameters in this study were modified from those similarly obtained by Gamack, 1992 and also compared very closely to that of Knox, et al. (2004) (Fig. 1). In addition it was crucial to evaluate the CEC soil potency as demonstrated from the result as shown (Tables 6, 7 and 8). For example the value of 2.43-7.40 $\mathrm{kcmol} / \mathrm{Kg}$ was observed indicating that CEC could be a major parameter in the adsorption capacity of the soil. Moreover the soil $\mathrm{pH}$ range indicated that the ionic characteristic of the held metallic complexes were not adversely affected by extreme alkaline or acidic conditions that normally complicate speciation of the metallic complexes. On the hand Red earth comparatively showed a degree of semblance to the Craibstone soil in $\mathrm{pH}$ values as indicated in Tables 5 and 6. However, the CEC value of Red earth was determined at $155 \mathrm{cmol} / \mathrm{kg}$ which higher than all the ameliorants shown in Table 6. In retrospect Bone meal was much more alkaline with a $\mathrm{pH}$ of 8.41 but comparatively a lower water holding capacity of $20.82 \%$ 
(Table 7). As an ameliorant the pH of PFA (8.1) (Table 8) was more comparable to the Bone meal but in contrast demonstrating a higher water holding capacity of $34.45 \%$. After the comparison of the characteristics of all the ameliorants shown (Tables 6, 7 and 8), the treatment effect where chemically analyzed to further determine the final lead concentration of the leachate using a graphite furnace Atomic adsorption

Table 5: Chemical and physical characteristics of Craibstone soil, (modified: Gamack, 1992)

\begin{tabular}{ll}
\hline Parameters & Characteristics \\
\hline Series & Countesswells \\
Total Pb & $5.02 \mu \mathrm{g} / \mathrm{g}$ \\
$\mathrm{pH}$ & $6.1(2.5: 1$ in \\
& deionised water $)$ \\
& $5.3\left(2.5:\right.$ in $\left.0.01 \mathrm{M} \mathrm{CaCl}_{2}\right)$ \\
Base saturation & $88.43 \%$ \\
Cation Exchange Capacity & $2.43-7.40 \mathrm{cmol} / \mathrm{kg}$ \\
Texture: Loamy Sand & Sand $74 \%$ \\
& Silt $20 \%$ \\
& Clay $6.11 \%$ \\
Density & $1.471 \mathrm{~g} \mathrm{~cm}{ }^{-3}$ \\
Organic Matter & $4.25-6.4 \%$ \\
Organic Carbon & $3.5 \%$ \\
\hline
\end{tabular}

Table 6: Characteristic of red earth

\begin{tabular}{ll}
\hline Parameters & Values \\
\hline $\mathrm{pH}\left(\mathrm{H}_{2} \mathrm{O}_{2}\right)$ & 5.9 \\
$\mathrm{pH}\left(\mathrm{CaCl}_{2}\right)$ & 5.1 \\
Total Pb & $175 \mathrm{mg} / \mathrm{kg}$ \\
Loss-on-ignition & $5.53 \%$ \\
Maximum Water Holding Capacity & $53.63 \%$ \\
Bulk Density (dry) & $1.29 \mathrm{gcm}^{-3}$ \\
CEC & $155 \mathrm{~cm}^{-\mathrm{lkg}}$ \\
\hline
\end{tabular}

Therefore to be able to authoritatively determine efficacy adsorption \% of each ameliorant it was necessary to measure their CEC (mol/g) values as shown in the results in Fig 2. For example Fig. 2 shows that red earth had the highest adsorption \% efficiency of over $96 \%$ of all the experimental samples tested. Bone meal was found to be the least of them with an adsorption efficacy of less than $92 \%$. This was a crucial result which demonstrated that apart form carrying out chemical analysis to determine the reduction of contaminants it is important to incorporate techniques that also are base CEC values. However, the determination of a chemical using biosensor to provide the total concentration of a contaminant is necessary. Therefore the determination spectrophotometry as shown in Table 9. The highest reduction was observed with Bone meal with $29.1 \mathrm{mg} /$ $\mathrm{L}$ for $\mathrm{PbS}$. PFA was highest with $\mathrm{PbNO}_{3}(21.01 \mathrm{mg} / \mathrm{L})$ and $\mathrm{PbSO}_{4}$ (53.32) as a contaminant. However Red earth and Bone meal showed a close relationship with 23.85 and $23.90 \mathrm{mg} / \mathrm{L}$ respectively. This result indicated that all ameliorants had a varied effect depending on the type of lead complexes involved as shown in Table 9.

Table 7: Characteristics of the bone meal used

\begin{tabular}{ll}
\hline Parameter & Value \\
\hline $\mathrm{pH}\left(\mathrm{H}_{2} \mathrm{O}_{2}\right)$ & 8.41 \\
$\mathrm{pH}\left(\mathrm{CaCl}_{2}\right)$ & 7.68 \\
Loss-on-ignition & $>0 \%$ \\
Total Pb & $<0.2$ \\
Maximum Water Holding Capacity & $20.82 \%$ \\
Bulk Density & $1.3 \mathrm{~g} \mathrm{~cm}^{-3}$ \\
CEC & $53.5 \mathrm{cmol}^{-} \mathrm{kg}$ \\
\hline
\end{tabular}

Table 8: Characteristics of the pulverised fly ash

\begin{tabular}{ll}
\hline \multicolumn{1}{c}{ Parameter } & \multicolumn{1}{c}{ Value } \\
\hline $\mathrm{pH}\left(\mathrm{H}_{2} \mathrm{O}\right)$ & 8.1 \\
$\mathrm{pH}\left(\mathrm{CaCl}_{2}\right)$ & 7.6 \\
Total $\mathrm{Pb}$ & $0.3 \mathrm{ppm}$ \\
Loss-on-ignition & $0.0 \%$ \\
Maximum Water Holding Capacity & $34.45 \%$ \\
Bulk Density & $0.47 \mathrm{~g} \mathrm{~cm}^{-3}$ \\
CEC & $76.4 \mathrm{cmol}^{-\mathrm{kg}}$ \\
\hline
\end{tabular}

Table 9: Comparison of treatment effects (bone meal/red earth/PFA) on mean lead concentration reduction

\begin{tabular}{lllll}
\hline \multicolumn{1}{c}{ Treatments } & \multicolumn{4}{c}{ Reduction on lead concentration (mg/L) } \\
\hline & $\mathrm{PbS}$ & $\mathrm{PbNO}_{3}$ & $\mathrm{PbSO}_{4}$ & $\mathrm{PbCO}_{3}$ \\
Red earth & 22.91 & 8.28 & 9.64 & 23.85 \\
Bone meal & 29.1 & 9.8 & 9.6 & 23.90 \\
PFA & 17.7 & 21.01 & 53.32 & 17.40 \\
\hline
\end{tabular}

of bioavailability potential of the contaminant is crucial. When soil samples spiked with various lead compounds $\left(\mathrm{PbNO}_{3}, \mathrm{PbCO}_{3}, \mathrm{PbSO}_{4}\right.$ and $\left.\mathrm{PbS}\right)$ were treated to Red earth a significant effect was observed $(\mathrm{p}<0.05)$ (with the exception of $\mathrm{PbCO}_{3}$ ) (Fig. 3). The highest difference was observed with $\mathrm{PbS}$ where on application of red earth significantly increased percentage bioluminescence from $63 \%$ \pm 7 to $100.3 \pm 2.9$. The differences in percentage bioluminescence between samples treated with/ without Red earth indicated the following trend; 
$\mathrm{PbS}>\mathrm{PbNO}_{3}>\mathrm{PbSO}_{4}$. Moreover the application of bone meal as an ameliorant had a significant $(\mathrm{p}<0.05)$ effect on lead spiked soils as demonstrated with the \% bioluminescence results. However, the effect of samples treated with bone meal was demonstrated only as a difference in toxicity levels between $\mathrm{PbNO}_{3}$ and its control $(p<0.05)$. On the hand the application of PFA treated lead spiked samples showed a significant increase $(p<0.001)$ in luminescence in all the treatments. Comparatively leachates from samples treated with PFA, the highest luminescence result was observed with $\mathrm{PbNO}_{3}(74 \% \pm 1.24)$, while the lowest was with $\mathrm{PbSO}_{4}(35.05 \% \pm 2.60)$. The highest difference was observed with $\mathrm{PbNO}_{3}$ (23.60\%) and $\mathrm{PbSO}_{4}(22.05 \%)$, with the lowest luminescence noted with PbS (2.24\%) (Fig. 3).

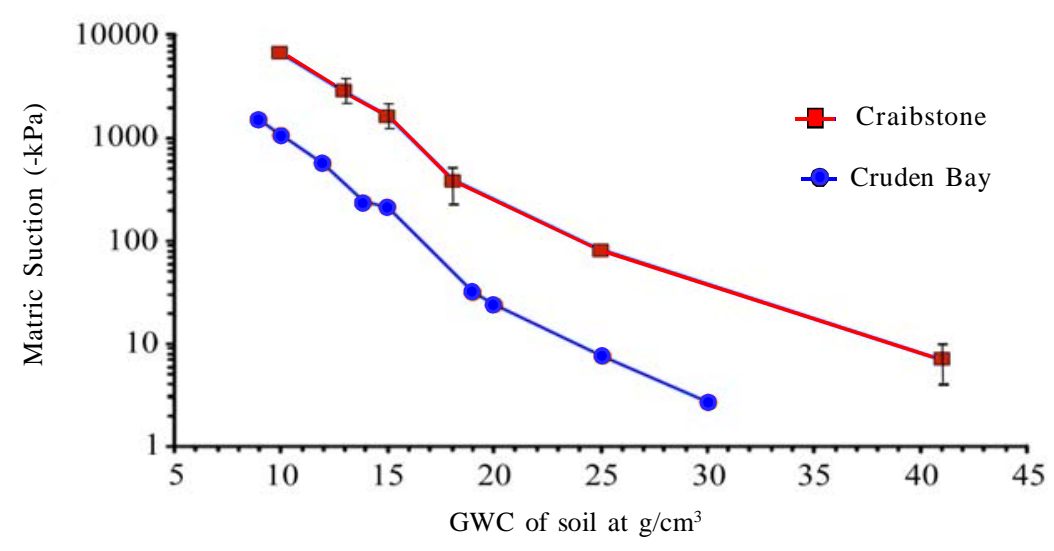

Fig. 1: Soil water uptake characteristics of soils Error bars represent the standard deviation of the mean $(n=6)$ (Knox et al., 2004)

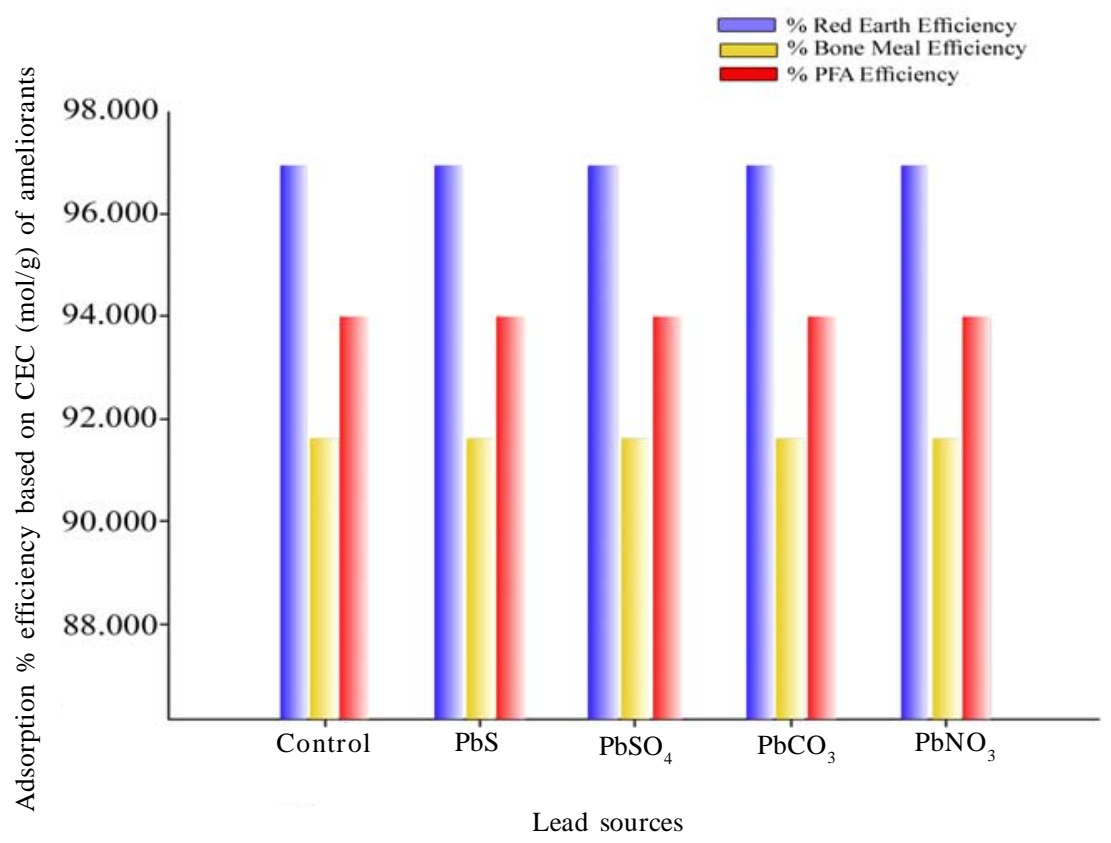

Fig 2: Efficiency of ameliorants to intercept lead leaching from soil amended with different lead compounds 


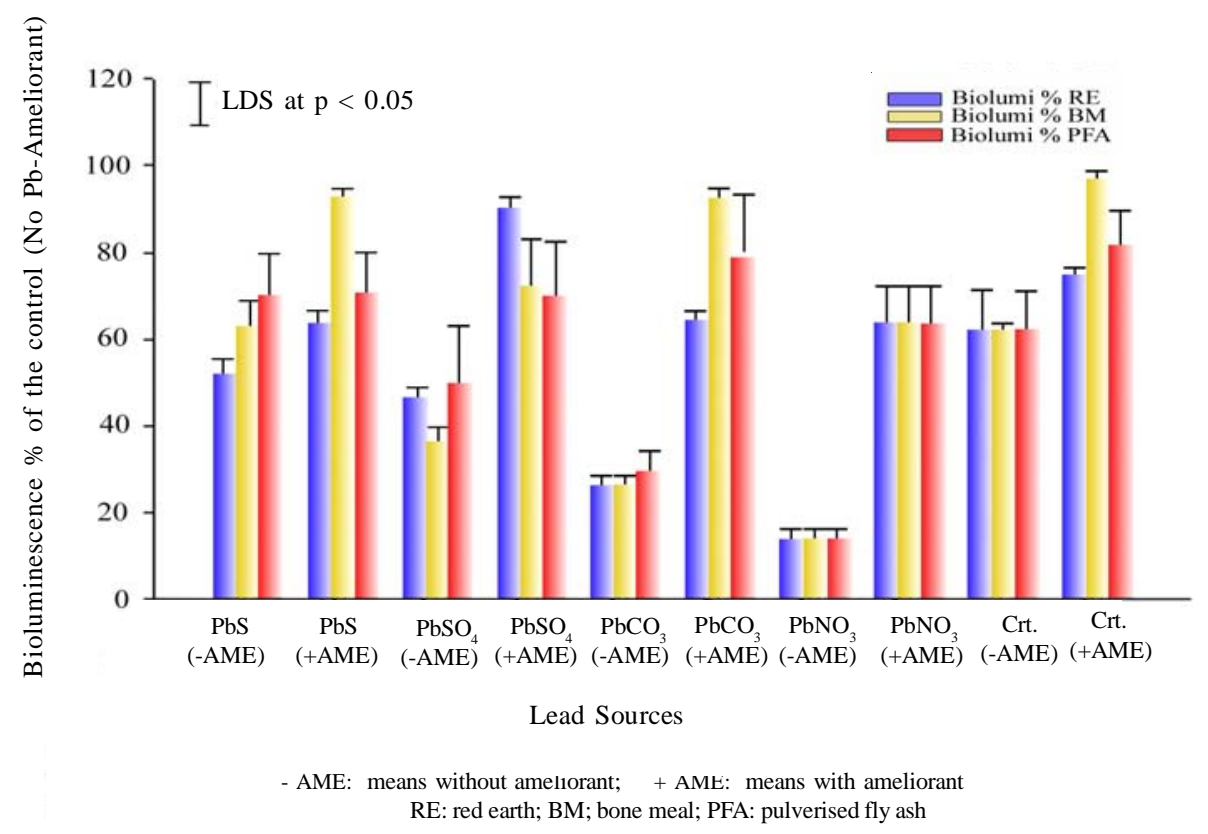

Fig. 3: Effect of ameliorant on Pb bioavailability in soils spiked with various lead compounds

\section{DISCUSSION AND CONCLUSION}

The study characterised the inherent properties of the soil and ameliorants, then determined their bioavailability of the lead fraction in the soil leachate. Finally the efficacy based on cation exchange capacity of red earth, bone meal and PFA was compared to determine their suitability as appropriate sources of ameliorating lead contaminated soils. Knox et al., (2004) reported on the characteristics of Craibstone soil (a Countesswells series sandy loam), with $73.9 \%$ sand, $20 \%$ silt, and $6.1 \%$ clay, 5\% organic matter andpH 6.2. However when compared to an earlier report of Gamack et al., (1992) a close comparison of the reported parameters was observed (Table 5). Soil water released and uptake characteristic of Craibstone was compared to Cruden bay soils (Tipperty series clay loam, with $43.4 \%$ sand, $32.3 \%$ silt, $24.3 \%$ clay, and $3 \%$ organic matter and $\mathrm{pH}$ 6.4) which was collected from arable sites in Aberdeenshire, Scotland (exhibiting lower water uptake) (Knox et al., 2004) (Fig. 1). This information was critical in understanding the characteristic of Craibstone soils used during this study, in the experimental pots. Artificial rain was used to wet the pots. Red earth/mud contains high concentrations of iron oxides (levels varying depending on pedogenetic processes) and some organic matter, and is reported to have a high capacity to adsorb $\mathrm{Pb}$ and concomitantly to maintain a low free $\mathrm{Pb}^{2+}$ activity in solution (Sauvé et al., 2000). Other beneficial attributes such as high CEC and water holding capacities are described in Table 6. Lombi et al., (2002) reported that red mud, as an amendment, shifted metals from the exchangeable to the $\mathrm{Fe}$ and $\mathrm{Al}$ oxide fraction, and decreased acid extractability of the metals. They further reported that specific chemisorptions, and possibly metal diffusion into oxide particles, could also be the mechanisms responsible for the fixation of metals by red mud. Therefore, the importance of red earth as an ameliorant cannot be overstated, especially considering that many current technologies used to remediate polluted soil are often too expensive. However red earth samples characterised by Lombi et al., 2002 showed a difference in $\mathrm{pH}$ (10.5) when compared to those in this study ( $\mathrm{pH}$ 5.9) (Table 6). This aspect was important because lead solubility is generally very low in non-acidic soils and therefore the amendments (ameliorants) used can only slightly reduce metal mobility (Cunningham and Berti, 2000). Thus the efficacy, low-cost and potential adsorbancy properties of red earth justified its use in 
this study as one of the ameliorants of choice. Bone meal contains lead, but at low concentrations $<0.2$ ppm (Hodson et al., 2000). According to the information supplied by John Hall Ltd, the bonemeal (sterilised to ensure that it is free of risk from BSE and pathogens) contained 3.5 wt. \% N and 8.6 - 8.7 wt. \% P with low contaminant concentrations, $45 \mu \mathrm{g} \mathrm{Zn/g;} 0.02 \mu \mathrm{g} \mathrm{Cu} /$ g; $0.05 \mu \mathrm{g} \mathrm{Ni} / \mathrm{g}$ and $0.2 \mu \mathrm{g} \mathrm{Pb} / \mathrm{g}$. Pb concentrations in bone meal indicated very low $\mathrm{Pb}$ concentrations as shown in Table 7. Bone meal was an ideal choice as an ameliorant (to remediate metal contaminated lands) due to its low-cost, readily available, high $\mathrm{P}$ content and the ability to release $\mathrm{P}$ without the risk of high solubility (without causing excessive $\mathrm{P}$ runoff e.g. $\mathrm{K}_{2} \mathrm{HPO}_{4}$ ) associated with other P forms (Valsami-Jones, 2000). The high solubility of most $\mathrm{P}$ source means that the eutrophication risk would be associated with such treatment (Hodson et al., 2000). In addition to mineral $\mathrm{P}$ sources such as Pyromorphites, rock apatite have also been successfully trialled (Ma et al., 1993), but rock apatite is highly insoluble (Nriagu, 1984) and so might not release $P$ sufficiently and rapidly to remediate contaminated soil on an acceptable time scale. Hodson et al., 2000 reported that the potential of bone meal as an ameliorant of metal contaminated soils was optimum under acidic and near neutral conditions. Therefore, bone meal as an ameliorant of choice exhibits' critical characteristic which include the ability to reduce metal released from contaminated soils, increase soil and leachate $\mathrm{pH}$ and decrease soil leachate toxicity with minimal Pleaching occurring. During the study, certain parameters associated with PFA were considered vital in terms of its role as an ameliorant (e.g maximum water holding capacity, CEC etc) as detailed in Table 8. Other related studies (Adriano et al., 1980; Aitken et al., 1984 and Gangloff et al., 2000) demonstrated that PFA is comprised primarily of fine sand and silt sized particles, and so if applied at sufficient rates it can be applied to change soil texture and to increase water holding capacity. Pathan et al., (2003) reported that PFA when applied (fine textured to coarse-textured sandy soils) not only substantially increase water holding capacity but also reduce soil hydraulic conductivity. PFA also provides a source of extractable $P$ and increase CEC. Fly ash particles are characterised with physical structures consisting of "hollow spheres" which show an increased surface area, capillary action, and nutrientholding capacity compared with sands (Fisher et al., 1976). Interest in the use of fly ash as a soil amendment (or ameliorant) results from (i) the need to develop sustainable uses of this by-product (Adriano et al., 1980; Bilski et al., 1995) and (ii) reports showing improved growth of some crops (El-Mogazi et al., 1988; Rees and Sidrak, 1956), pasture (Hill and Lamp, 1980 and Summers et al., 1998), and after turf species (Adriano and Weber, 2001 and Pathan et al., 2001), following addition of fly ash to some soils. Therefore the choice of PFA (ameliorant) was based on the potential of its efficacy over a wide range of $\mathrm{pH}$, and with reference to associated phenomena occurring at the oxide/water interface (Stumm, 1992), such as ion exchange, adsorption, surface precipitation and bulk solution precipitation which can be attributed to the effective removal of heavy metals in aqueous solution by fly ash (Ricou et al., 1999). When all the ameliorants were compared, as earlier discussed and shown in Table 9, both Red earth and Bone meal had the highest effect on $\mathrm{PbCO}_{3}$ This observation was indicative of speciation specificity of the lead compound when treated to different ameliorants. Further analysis of the data suggested that it is important to identify the predominant species of the contaminant before applying untested ameliorant for remediation purposes. Therefore the need to investigate the association of lead reduction in the soil leachate with the adsorption potential of the ameliorants was necessary.

\section{Comparison of the efficacy of the ameliorants.}

The measurement of the reduction of lead concentration $(\mathrm{mg} / \mathrm{L})$ (Table 9 ) was not sufficient to assess the efficacy of the ameliorants without integrating the individual CEC values of the ameliorants (Red earth/mud, Bone meal and PFA) (Fig. 2). Moreover the added advantage of evaluating the efficacy of the ameliorants based on CEC was not only on how efficient a particular ameliorant adsorbs the contaminant but subsequently how its application becomes cost effective. When the efficacy of the ameliorants were individually analysed the results were varied between the lead compound sources and amongst the ameliorants compared. The results evaluating the efficiency of Red earth/mud based on CEC values as earlier indicated was associated with the lowest release to the leachate compared to the control (96.92346\% efficiency based on CEC in moles $100 \mathrm{~g}^{-1}$ ) (Fig. 2). The efficiency indicated that the adsorption potential of the ameliorant for lead from $\mathrm{PbSO}_{4}$ (96.92343), when considered in terms of ameliorant CEC showed a much 
higher value in comparison to the other lead compounds. While the efficiency of bone meal based on CEC value results, indicated that $\mathrm{PbCO}_{3}(91.57808$ $\%$ efficiency based on CEC in moles $100 \mathrm{~g}^{-1}$ ) was associated with the lowest release to the leachate compared to the control (91.57823\% efficiency based on CEC in moles $100 \mathrm{~g}^{-1}$ ) (Fig. 2). Therefore the efficiency indicated that the adsorption potential of the ameliorant of lead from $\mathrm{PbNO}_{3}$, when considered in terms of the ameliorant CEC showed a much higher value in comparison to the other lead compounds. It was also necessary to investigate the efficacy of PFA as an ameliorant by evaluating its CEC value (Fig. 2) as a potential source of adsorbance to mobile lead from soil spiked with different lead compounds. The highest efficiency of the ameliorant was observed with soils spiked with $\mathrm{PbSO}_{4}$ (93.94975\%). However when all three ameliorants were compared with each other, the highest efficiency was demonstrated with Red earth indicating an efficiency value greater than all the other ameliorants (Fig. 2). Essentially evaluation of Red earth/mud efficiency to intercept lead leaching from soil amended with different lead compounds based on CEC (mol/g), confirmed the adsorption potential (> 96.9234\% for all samples) of the ameliorant which was higher than the other ameliorants (Fig. 2). A similar observation related to the efficacy of red earth as an ameliorant was noted by Friesl et al. (2003), where all soils spiked with Zn and $\mathrm{Ni}$ showed a reduction in metal leaching on application of red mud. In this regard sesquioxides are considered to play an important role in the immobilisation of heavy metals (Kabata-Pendias and Pendias, 1992), the process generally involving two main steps. Firstly, there is fast surface adsorption which depends on CEC and specific adsorption that is related to metal ion hydrolysis followed by a slow process consisting of the substitution of a matrix ion, the occlusion by re-crystallization and diffusion into sesquioxides pores (Brümmer et al., 1986). The heterogeneous adsorbency principle in red mud is associated with its ability to bind metal ions $\left(\mathrm{M}^{2+}\right)$ onto one or two types of surface sites at $\mathrm{pH}<6.0$ and less than $50 \%$ surface coverage in the form of $\mathrm{SOM}^{+}$ monodentate surface complex, which results in the release of protons from the surface, effectively explaining the adsorption of metals (Apak et al., 1998). This observation was supported by a report by Sauvè et al., (2000) who indicated that the presence of Iron oxides (Red earth/mud) and also organic matter had a high capacity to adsorb $\mathrm{Pb}$ and concomitantly maintain a low free $\mathrm{Pb}^{2+}$ activity in solution. The addition of red earth/mud to metal contaminated soils generally causes the shifting of metals from the exchangeable to the Feoxide fraction, and decreases acid extractability of metals (Brown et al., 2005). The mechanisms proposed by Lombi et al. (2002) suggest that specific chemisorption, and possibly metal diffusion into oxide particles could be the mechanisms responsible for the fixation of metal by red mud. When Red Earth is added to contaminated soils, they can neutralise low $\mathrm{pH}$ and reduce metal mobility by different physical chemical mechanisms (increase of available adsorption sites) (Lombi et al., 2002).

\section{Biosensor based toxicity test of the leachate}

The choice of the biosensor was appropriate due to its robust, wide $\mathrm{pH}$ ranges (3.0-10.00) and sensitivity in measuring the toxicity of the final leachate collected (Palmer et al., 1998). To ascertain that the application of the ameliorants to the lead spiked soils had a toxicity reduction effect on the soil sample leachate, a toxicity test based on a lux-biosensor was used (Fig. 3).The results compared the toxicity effect between several lead sources with the application of individual ameliorants (Red earth, Bone meal and PFA). Overall, the application of the ameliorants appeared to reduce metal release from heavily contaminated soils rendering the final leachate less toxic. Shende et al. (1994) for instance, used alkaline Fly Ash to reduce the metal toxicity of contaminated soil through immobilization of heavy metals. However, these workers found that when the Fly Ash application exceeded 5\% on a weight for weight basis in soil, growth of maize (Zea mays) grown in acidic sandy loam ( $\mathrm{pH} 4.9)$ and calcareous silty clay ( $\mathrm{pH} 7.9)$ soils treated with known concentrations of heavy metals (viz. cadmium, copper, nickel and zinc) was significantly reduced. The adsorption properties of PFA were also related to its ability in immobilizing heavy metals. Similarly studies by Wang et al., (2004) investigated on the characterisation of metal adsorption capability of coal Fly Ash (class F), it was established that the surface physical-chemical characteristics of a class F coal Fly Ash had a quantitative relationship with metal adsorption. The linkage of CEC to adsorption potential carried out in the current study (Fig. 3) was also supported by Chien-Jung Lin et al., (1999) who investigated the effect of applying Fly Ashes to remove 
metal ions from wastewater and concluded that the cation exchange capacity and specific surface area of Fly Ashes increased with increasing carbon content, and consequently, carbon residual in the Fly Ashes played a much more important role than the mineral content in the removal of metal by the Fly Ashes. To complement the results related to the efficacy of the ameliorants based on CEC, further analysis of the biosensor data on leachate toxicity showed that the application of red mud had rendered the leached fraction of the spiked lead less toxic, indicated by an increase in percentage bioluminescence upon its application. The only lead compound which showed a degree of toxicity even after the application of Red mud after 193 days was PbS. This could probably be attributed to the low solubility of lead sulphide when spiked into soil samples. Bataillard et al., (2003) showed that when lead was added as sulphate, between 10 and $20 \%$ of lead particles dissolved, regardless of the soil type ultimately with lead sulphide progressively oxidising over time. This observation was also observed during the current study. In comparison to the other lead sources, PbS (as indicated earlier (Fig. 2)) had lower adsorption percentage efficiency in comparison to $\mathrm{PbSO}_{4}$. Therefore red earth/mud application as an in situ inactivation technique (where an ameliorant is incorporated and mixed with lead contaminated soil) bound the toxic metals which, essentially reduced the pollutant mobility in the soil thus reducing the contaminant leachability and bioavailability fraction (Hartley et al., 2004). Moreover, the advantages of Red mud/earth which relate to factors such as retention of nutrients on infertile sandy soils, reduction of eutophication of rivers and water ways (Summers et al., 1996a), groundwater recharge areas, improvement of pasture growth (Summers et al., 1996b), plant P uptake (Snars et al., 2004) and water retention in excessively drained soils (Vlahos et al., 1989) outstripped the disadvantages. Also as demonstrated earlier, the high adsorption efficiency of Red earth was associated with the low application rates (6.92 g/kg soil) in comparison to Bone meal (20 g/ kg soil) and PFA (14.08 g/kg soil). The disadvantages that were attributed to red earth/mud include high $\mathrm{pH}$ values, salinity, and absence of nutrients and organic constituents that could possibly suppress revegetation (Xenidis et al., 2005). However precautionary principle is highly required as a public health concern for wide application of red earth/mud where off-site assessment is conducted before use to avoid recontamination of terrestrial or aquatic systems. The control and reduction of waste volumes in landfills consisting of red earth, bone meal and PFA as by- products of a variety of processing industries and addressing potential of those wastes as interceptors of mobile metals, initiated these studies to evaluate amelioration as a technique in remediation of contaminated lands. Most of the ameliorants are by products of industrial processes and are normally considered to be an environmental nuisance and therefore offered free or at very minimal rates. Thus the general costs associated with the ameliorants will be based on transportation and application costs in situ. During the ameliorant characterisation stages of this study and comparison of related reviews, several advantages to the use of the three ameliorants were noted. These included aspects such as cost effectiveness, adsorption capacity, ion exchange, bulk solution precipitation, water holding capacity and reduction of mobility of metal contaminants which potentially out weighed existing engineering based remediation technologies. However the results based on most of the parameters mentioned indicated that red earth was at most highly efficient as an ameliorant in comparison to bone meal and PFA. Further assessment on its use per cost of in situ application needs to be tied with its efficacy on adsorption based on CEC during remediation. Furthermore other areas need to be studied and assessed (for public health concerns) in depth for wide spread application of the mentioned ameliorants (in terrestrial and aquatic ecosystems) to include off-site effects of the ameliorants (e.g. trace metals, cyanide etc).

\section{REFERENCES}

ACI, (1987). Use of fly ash in concrete. ACI materials Journal, ACI Committee 226. 3R-87, (84-M39), 381-409.

Adriano, D. C. and Weber, J. T., (2001). Influence of fly ash on soil physical properties and turf grass establishment. J. Environ. Qual., 30, 596-601.

Aitken, R. L., Campbell, D. J. and Bell, L. C., (1984). Properties of Australian fly ashes relevant to their agronomic utilization. Aust. J. Soil Res., 22, 443-453.

Adriano, D. C., Page, A. L., Elseewi, A. A., Chang, A. C. and Straughan, I., (1980). Utilisation and disposal of fly ash and other coal residues in terrestrial ecosystems: A review. J. Environ. Qual., 9, 333-344.

Allen, H. E., (1989). Chemical analysis of ecological materials.

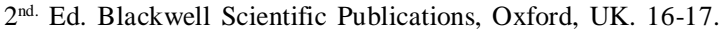

Alp, A. and Goral, M. S., (2003). The effects of the additives, calculation and leach conditions for alumina production from red mud. Scand. J. Metall., 32, 301-305. 
Alvarez, J., Ordonez, S., Rosal, R., Sastre, H. and Dez, F. V., (1999). A new method for enhancing the performance of red mud as a hydrogenation catalyst. Appl. Catal., 180 (1), 399-409.

Amin-Hanjani, S., Meikle, A., Glover, L. A., Prosser, J. I. and Killham, K., (1993). Plasmid and chromosomally encoded luminescence marker systems for detection of Pseudomonas fluorescens in soil. Mol. Ecol., 2, 47-54.

Apak, R. and Ünseren, E., (1987). Flocculation in biotechnology and separation systems. Procedings, Elsevier, Amsterdam. 765.

Avery, B. W. and Bascomb, C. L., (1974). Soil survey laboratory methods. Soil survey technical monograph No. 6, Harpenden.

Bataillard, P., Cambier, P. and Picot, C., (2003). Short term transformation of lead and cadimium compound in soil after contamination. Eur. J. Soil Sci., 54, 365-376.

Bilski, J. J., Alva, A. K. and Sajwan, K. S., (1995). Fly ash. In J. E. Rechcigl (Ed.) Soil amendments and environmental quality. CRC Press, Boca Raton, FL., 327-363.

Brown, S., Christensen, B., Lombi, E. and McLaughlin, M., (2005). An inter- laboratoiry study to test ability of amendments to reduce the availability of $\mathrm{Cd}, \mathrm{Pb}$, and $\mathrm{Zn}$ in situ. Environ. Pollut., 138, 34-35.

Brümmer, G. W., Gerth, J. and Hermes, U., (1986). Heavy metal species, mobility and availability in soils. Z. Pflanzenernaehr. Bodenk, 146, 382-398.

Chaudhuri, D., Tripathy, S., Veeresh, H., Powell, M. A. and Hart and B. R., (2003). Mobility and bioavailability of selected heavy metals in coal ash and sewage sludge-amended acid. Environ. Geol., 44, 419-432.

Chien Jung, L., Juu-En, Ch. and Ming-Chun, L., (1999). Application of fly ashes in the removal of metal ions from wastewater. Paper presented at the R'99 Congress

(recovery, recycling, Re-integration). World Congress, Geneva.

Cotter Howells, J. and Caporn, S., (1996). Remediation of contaminated land by formation of heavy metal phosphates. Appl. Geochem., 11, 335-342.

Cunningham, S. D. and Berti, W. R., (2000). Phytoextraction and phytostabilization: Technical, economic and regulatory considerations of the soil-lead issue.In Terry, $\mathrm{N}$ and Banuelos, G., (Ed.) Phytoremediation of contaminated soil and water. Lewis Publ., Boca Raton, FL., USA, 359-376

Cunningham, S. D., Berti, W. R., Huang, J. W., (1995). Phytoremediation of contaminated soils. Trends Biotechnol., 13, 393-397.

El-Mogazi, D., Lisk, D. J. and Weinstein, L. H., (1988). A review of physical and chemical, and biological properties of fly ash and effects on agricultural ecosystems. Sci. Total Environ., 74, 1-37.

Fisher, G. L., Chang, P. D. Y. and Brummer, M., (1976). Fly ash collected from electrostatic precipitators: Microcriostalline structures and the mystery of the spheres. Science (Washingtoin, DC), 129, 553-555.

Friesl, W., Lombi, E., Horak, O. and Wenzel, W. W., (2003). Immobilisation of heavy metals in soils using inorganic amendments in a greenhouse study. J. Plant Nutr. Soil Sci., 166, 191-196.

Gammack, S. M., Paterson, E., Kemp, J. S., Cresser, M. S. and Killham, K., (1992). Soil biochemistry. Eds. Stotzy G., Bollag J. M., 7, 263-306.
Gangloff, W. J., Ghodrati, M., Sims, J. T. and Vasilas, B. L, (2000). Impact of fly ash amendment and incorporation method on hydraulic properties of a sandy soil. Water Air Soil Poll., 119, 231-245.

Gupta, V., Gupta, M. and Sharma, S. (2001). Process development for the removal of lead and chromium from aqueous solutions using red mud - an aluminium industry waste. Water Res., 35, 1125-1134.

Hartley, W., Edwards, R. and Lepp, N. W., (2004). Arsenic and heavy metal mobility in iron oxide-amended contaminated soil as evaluated by short- and long-term leaching tests. Environ. Pollut., 131, 495-504.

Hill, M. J. and Lamp, C. A., (1980). Use of pulverized fuel ash from Victoria brown coal as a source of nutrients for a pasture species. Aust. J. Exp. Agric. Anim. Husb., 20, 377384.

Hodson, M. E., Valsami-Jones, E., and Cotter-Howells, J. D., (2000). Bone meal addition as a remediation treatment for metal contaminated soil. Environ. Sci. Technol., 34, 35013507.

Hodson, M. E., Valsami-Jones, E., Cotter-Howells, J. D., Dubbin, W. E., Kemp, A. J., Thornton, I., Warren, A., (2001). Effect of bone meal (calcium phosphate) amendments on metal release from contaminated soils-a leaching column study. Environ. Pollut., 112, 233-243.

Hodson, M. E. and Valsami-Jones, E., (1999). Remediation of toxic pollution in soils using bone meal. Fifth bi-monthly report. The Department of Mineralogy, Natural History Museum. Cromwell Road.

Kabata-Pendias, A. and Pendias, H., (1992). Trace elements in soils and plants, $2^{\text {nd. }}$ Ed, CRC Press, Boca Raton, FL., USA.

Knox ,O. G. G., Killham, K., Artz, R. R. E., Mullins, C. and Wilson, M., (2004). Effect of nematodes on rhizosphere colonization by seed applied bacteria. Appl. Environ. Microb., 70, 4666-4671.

Lombi, E., Zhao, F. J., Zhang, G., Sun, B., Fitz, W., Zhang, H. and McGrath, S. P., (2002). In situ fixation of metals in soils using bauxite residue: Chemical assessments. Environ. Pollut., 118, 435-443.

Ma, Q. Y., Logan, T. J., Ryan, J. A., (1993). In situ lead immobilization by apatite. Environ. Sci. Technol., 27, 18031810 .

Macek, T., Macková, M. and Kás, J., (2000). Exploitation of plants for the removal of organics in environmental remediation. Biotechnol. Adv., 18, 23-34.

Mwinyihija, M., Meharg, A., Strachan, N. J. C. and Killham, K., (2005). Ecological risk assessment of the Kenyan tannery industry. J. Am. Leather Chem. As., 100 (11), 466-472.

Mwinyihija, M., Dawson, J., Meharg, A., Strachan, N. J. C. and Killham, K., (2006). An ecotoxicological approach to assessing the impact of tanning Industry effluent on river

health. Arch. Environ. Contam. Toxicol., 50 (3), 316-324.

Nguyen, Q. D. and Boger, D. V., (1998). Application of rheology to solving tailings disposal problems. Int. J. Miner. Process, 54, 217-233.

Nriagu, J. O., (1984). Formation and stability of base metal phosphates in soils and sediments. In Phosphate Minerals Nriagu J. O. and Moore P. B. Spring-Verlag, London, UK, 318-329. 
Palmer, G., McFadzen, R., Killham, K., Sinclair, A., Paton, G. I., (1998). Use of lux-based biosensors for rapid diagnosis of pollutants in arable soils. Chemosphere. 36, 2683-2697.

Pathan, S. M., Aylmore, L. A. G. and Comer, T. D., (2001). Fly ash amendment of sandy soils to improve water and nutrient use efficiency in turf culture. Int. Turfgrasse Soc. Res. J., 9, 33-39.

Pathan, S. M., Aylmore, L. A. G., and Colmer, T. D., (2003). Properties of several fly ash materials in relation to use as soil amendments. J. Environ. Qual., 32 (2), 687-693.

Rees, W. J. and Sidrak, G. H., (1956). Plant nutrition on fly ash. Plant Soil, 8, 141-157.

Ricou, P., Hequet, V., Lecuyer, I. and Le Cloirec, P., (1999). Influence of operation conditions on heavy metal cation removal by fly ash in aqueous solutions. International Ash Utilisation Symposium, Centre for Applied Energy Research, University of Kentucky, 42.

Salt, D. E., Smith, R. D., Raskin, I., (1998). Phytoremediation. Annu. Rev. Plant Phys., 49, 643-668.

Sauvé, S., Enid, M., McBride, M. and Hendershot, W., (2000). Adsorption of free lead $\left(\mathrm{Pb}^{2+}\right)$ by pedogenic oxides, Ferrihydrite, and leaf compost. Soil Sci. Soc. Am. J., 64, 595-599.

Sear, L. K. A, Weatherley, A. J. and Dawson, A., (2003). Environmental impacts of using fly ash: the UK Producers Perspective. International Ash Utilisation Symposium, Centre for Applied Energy Research, University of Kentucky.

Shaw, J. J. and Kado, C. I., (1986). Development of a vibrio bioluminescence gene-set to monitor phytopathogenic bacteria during the ongoing disease process in a nondisruptive manner. Biotechnol., 4, 560-564.

Shende, A., Juwarkar, A. S. and Dara, S. S., (1994). Use of fly ash in reducing heavy metal toxicity to plants. Resour. Conserv. Recy., 12, 221-228.
Snars, K., Hughes, J. C. and Gilkes, R. J., (2004). The effects of addition of bauxite red mud to soil. Aust. J. Agr. Res. 55 (1), 25-31.

Stumm, W., (1992). Reductive dissolution of manganese (III, IV) (hydr) oxides by oxalate: the effect of $\mathrm{pH}$ and light. Langmuir., 8, 95-103.

Summers, R., Clarke, M., Pope, T. and O’Dea, T., (1998). Western Australian fly ash on sandy soils for clover production. Commun. Soil Sci. Plant Anal., 29, 2757-2767.

Summers, R. N., Guise, R. N., Smirk, D. D. and Summers K. J., (1996a). Bauxite residue (red mud) improves pasture growth on sandy soils in Western Australia. Aust. J. Agr. Res., 34 (4), 569-581.

Summers, R. N., Smirk, D. D., Karafilis, D., (1996b). Phosphorus retention and leachates from sandy soil amended with bauxite residue (Red Mud). Aust. J. Soil. Res., 34 (4), 555-567.

ValsamiJones, E., (2000). British geological survey. Regional Geochemistry of parts of Northwest England and North Wales. Geol. Mag., 137, 336-337.

Vlahos, S., Summers, K. J., Bell, D. T. and Gilkes, R. J., (1989). Reducing phosphorous leaching from sandy soils with red mud bauxite processing residues. Aust. J. Soil Res., 27 (4), 651-662.

Wang, J., Teng, X., Wang, H., Ban, H., (2004). Characterizing the metal adsorption capacity of a class F coal fly ash. Environ. Sci. Technol., 38, 6710-6715.

Wood, P. A, (1997). Remediation methods for contaminated sites. In contaminated land and its reclamation R. E. Hester and R. M. Harrison Eds., Thomas Telford Publishing, London, 47-71.

Xenidis, A., Harokopou, A. D., Mylona, E., Brofas, G., (2005). Modifying alumina red mud to support a revegetation cover. JOM-J. Occup. Med., 57 (2), 42-46.

\section{AUTHOR(S) BIOSKETCHES}

Gatima, E., M.Sc., MPhil., His current interest is in the field of lead toxicity behaviour and speciation in the terrestrial systems. Email:e.gatima@abdn.ac.uk

Mwinyihija, M., Ph.D., The current research interests are in the field of ecotoxicology especially in areas of contaminant fate in terrestrial and aquatic ecosystems, diagnostic's using microbial biosensor application in environmental samples and applied bioremediation techniques. Email:mmwinyi@gmail.com

Killham, K., Ph.D., is the Chair of Soil Science and Director of Research, School of Biological Sciences (Plant and Soil Science), University of Aberdeen. He is a Fellow of the Royal Society of Edinburgh and a Fellow of the American academy of Microbiology. He is a leading consultant (ecotoxicology and environmental microbiology). His current research interest includes rhizosphere biological interactions, microbial biosensors, bioremediation and carbon/nutrient cycling.

Email:k.killham@abdn.ac.uk

This article should be referenced as follows:

Gatima, E., Mwinyihija, M. and Killham, K., (2006). Determination of adsorption efficiency based on cation exchange capacity related to red earth, bone meal and pulverised fly ash as ameliorants to lead contaminated soils. Int. J. Environ. Sci. Tech., 3 (3), 269-280. 